\title{
KEPUASAN MASYARAKAT TERHADAP PERS BERBAHASA SUNDA
}

\author{
Parulian Sitompul \\ Balai Pengkajian dan Pengembangan Komunikasi dan Informatika Bandung (BPPKI) Bandung \\ Jl.Pajajaran No.88 Bandung-40173, Jabar, Telp.022-6017493, Fax.022-6021740 \\ HP. 085262374822.E-mail: paru001@kominfo.go.id \\ Dida Dirgahayu \\ Balai Pengkajian dan Pengembangan Komunikasi dan Informatika Bandung (BPPKI) Bandung \\ Jl.Pajajaran No.88 Bandung-40173, Jabar, Telp.022-6017493, Fax.022-6021740 \\ HP. 081573761965.E-mail: dida.bandung@yahoo.co.id \\ Naskah diterima tanggal 15 Oktober 2013, direvisi tanggal 6 Juni 2014, disetujui tanggal 12 Juni 2014
}

\section{COMMUNITY SATISFACTION OF SUNDANESE LANGUAGE PRESS}

\begin{abstract}
The 1960s could be called the golden age of Sunda press. At the present time the press Sunda suffered a setback in a various of activities. While in the middle of advancements in printing and layout technology, Sundanese language press is currently lagging far behind the national press. The research problem is how people's satisfaction to Sundanese language press. Therefore, the purpose of the study was to determine the motive, knowledge, and community satisfaction of the Sundanese language press. Method used is descriptive quantitative. Sample of 50 respondents which is $10 \%$ of the entire community reading Sundanese language press in the two districts of Bogor City. The results showed that the communitiy's motivation to read the Sundanese language press because of the Sundanese language used, and used by all members of the family. In addition, community already knows the function of the Sundanese language press. Eventhough it has not met their expectations, but the people are satisfied with the existence of Sundanese language press that they read.
\end{abstract}

Keywords: appreciation, community, Sundanese language press.

\begin{abstract}
Abstrak
Tahun 1960-an bisa disebut sebagai masa keemasan pers Sunda. Pada saat sekarang pers Sunda mengalami kemunduran dalam berbagai aktivitasnya. Di tengah kemajuan teknologi cetak dan tata rupa, pers berbahasa Sunda pada saat ini telah tertinggal jauh dibandingkan dengan pers nasional. Permasalahan penelitian ini adalah bagaimana kepuasan masyarakat terhadap pers berbahasa Sunda. Tujuan penelitian adalah untuk mengetahui motif, pengetahuan, dan kepuasaan masyarakat terhadap pers berbahasa Sunda. Metode yang digunakan adalah deskriptif kuantitatif. Sampel sebanyak 50 responden yaitu 10\% dari seluruh masyarakat pembaca pers berbahasa Sunda di dua kecamatan Kota Bogor. Hasil penelitian menunjukkan bahwa motif masyarakat membaca pers berbahasa Sunda karena bahasa Sunda dipergunakan dan dimanfaatkan oleh semua anggota keluarga. Masyarakat sudah mengetahui fungsi pers berbahasa Sunda.Walaupun belum memenuhi harapan, namun masyarakat puas terhadap keberadaan pers berbahasa Sunda yang dibacanya.
\end{abstract}

Kata kunci: apresiasi, masyarakat, pers berbahasa Sunda 


\section{PENDAHULUAN}

Secara umum pers berbahasa Sunda merupakan bagian dari bentuk media massa, khususnya media massa cetak. Pers berbahasa Sunda ini dapat disebut sebagai pers lokal. Mulyana menyebutkan yang dimaksud dengan pers lokal adalah pers yang dibangun oleh dan untuk lokal. Lokal di sini diartikan sebagai kota, kabupaten, dan provinsi (Mulyana, 2004).

Pekerjaan media pada hakikatnya tanpa kecuali seperti pers lokal berbahasa Sunda adalah mengonstruksikan realitas di masyarakat melalui suatu pembingkaian (framing). Tentu yang dibingkai adalah isi media tersebut. Isi media merupakan hasil para pekerja media yang mengonstruksikan berbagai realitas di lapangan yang dipilihnya sesuai dengan kebutuhan. Disebabkan sifat dan faktanya bahwa pekerjaan media massa adalah menceritakan peristiwa-peristiwa, maka seluruh isi media adalah realitas yang telah dikonstruksikan dan juga pekerjaan yang melibatkan banyak orang (Ardianto, dkk 2007).

Isi media pada hakikatnya adalah hasil konstruksi realitas dengan bahasa sebagai perangkat dasarnya, seperi bahasa Sunda. Bahasa bukan saja sebagai alat merepresentasikan realitas, namun juga bisa menentukan relief seperti apa yang akan diciptakan oleh bahasa tentang realitas yang disajikan dalam konteks pembangunan masyarakat Sunda secara umum (Dilla, 2007).

Hasil pertemuan semiloka bertema "Prospek dan Tantangan Pers Sunda dalam Dinamika Lintas Budaya" di kampus STIKOM Bandung beberapa waktu lalu, di antaranya dinyatakan bahwa pers Sunda mengalami kemunduran luar biasa sejak tahun 1970-an. Kemunduran pers Sunda menurut beberapa pengelolanya akibat pers berbahasa Indonesia tumbuh semakin profesional. Namun pada pers berbahasa Sunda sebaliknya. Masalah lainnya adalah karena persoalan kemajuan teknologi komunikasi yang mana pers Sunda belum mampu mengidentifikasi kebutuhan masyarakat Sunda. Puncak kejayaan penerbitan pers berbahasa Sunda terjadi pada kurun waktu tahun 1960-an bisa disebut sebagai masa keemasan pers Sunda. Kondisi saat ini, pers berbahasa Sunda dinilai mengalami kemunduran dalam berbagai aktivitasnya. Di tengah kemajuan teknologi cetak dan tata rupa, pers Sunda telah tertinggal jauh dibandingkan dengan pers nasional. Harapan masih ada di kalangan masyarakat, khususnya pembaca/pelanggan, terhadap pers berbahasa Sunda, seperti Galura, Mangle, Giwangkara, Sunda Midang, Cupumanik, terbitan tersebut mampu mempertahankan keberadaannya karena memunyai komunitas pembaca masingmasing (Majalah Gatra, 2006).

Berdasarkan kondisi dan realitas itulah penelitian yang berjudul "Kepuasan Masyarakat tehadap Pers Berbahasa Sunda" dilakukan untuk mengungkap persoalan apakah pers berbahasa Sunda sudah mampu mengidentifikasi pembacanya dalam upaya mempertahankan dan meningkatkan keberadaan atau eksistensinya yang diukur oleh seberapajauh kepuasan masyarakat terhadap pers berbahasa Sunda.

Permasalahan yang akan diangkat dalam penelitian ini, diidentifikasi sebagai berikut: (1) Sejauhmana motif masyarakat membaca pers berbahasa Sunda; (2) Sejauhmana pengetahuan masyarakat tentang pers berbahasa Sunda; (3). Sejauhmana kepuasaan masyarakat terhadap pers berbahasa Sunda.

Tujuan penelitian ini adalah untuk mengetahui: (1) Motif masyarakat membaca pers berbahasa Sunda; (2) Pengetahuan masyarakat tentang pers berbahasa Sunda; (3) Kepuasaan masyarakat terhadap pers berbahasa Sunda.

Kegunaan penelitian ini adalah mendukung kebijakan Kominfo khususnya Direktorat Jenderal Informasi dan Komunikasi Publik (IKP) Kementerian Komunikasi dan Informatika RI tentang apresiasi masyarakat, khususnya pembaca pers berbahasa Sunda dalam upaya memberikan bahan pijakan dalam membuat kebijakan yang berkaitan dengan pengembangan media berbahasa daerah. Penelitian ini juga berguna sebagai bahan 
masukan kajian ilmiah bagi pengelola media massa/pers berbahasa Sunda dalam upaya menjalankan fungsi media kepada masyarakat pembacanya.

\section{LANDASAN KONSEP}

\section{Pers berbahasa Sunda}

Undang-Undang Nomor 40 Tahun 1999 tentang Pers, pada Bab 1 Ketentuan Umum pasal 1 menyatakan bahwa Pers adalah lembaga sosial dan wahana komunikasi massa yang melaksanakan kegiatan jurnalistik meliputi mencari, memeroleh, memiliki, menyimpan, mengolah, dan menyampaikan informasi baik dalam bentuk tulisan, suara, gambar, suara dan gambar, serta data dan grafik maupun dalam bentuk lainnya dengan menggunakan media cetak, media elektronik, dan segala jenis saluran yang tersedia. Perusahaan pers adalah badan hukum Indonesia yang menyelenggarakan usaha pers meliputi perusahaan media cetak, media elektronik, dan kantor berita, serta perusahaan media lainnya yang secara khusus menyelenggarakan, menyiarkan, atau menyalurkan informasi. Pers nasional adalah pers yang diselenggarakan oleh perusahaan pers Indonesia, dan pers asing adalah pers yang diselenggarakan oleh perusahaan asing.

Dalam konteks penelitian ini, pers berbahasa Sunda adalah nasional atau pers daerah yang terbit di wilayah Provinsi Jawa Barat dengan bahasa yang dipergunakan adalah bahasa Sunda, di antaranya adalah Surat Kabar Mingguan (SKM) Galura, Majalah Mingguan Mangle, SKM Giwangkara, dan lain-lain.

\section{Teori Uses and Gratification}

Landasan pemikiran dalam pembahasan penelitian ini adalah teori Uses and Gratifications. Teori ini tidak tertarik pada apa yang dilakukan media massa pada diri orang, akan tetapi tertarik pada apa yang dilakukan orang terhadap media. Dalam hal ini penekanannya adalah pada aktivitas khalayak dalam menggunakan media untuk memenuhi kebutuhannya (Rakhmat, 1985).
Model Uses and Gratifications (Model Kegunaan dan Kepuasan) merupakan pengembangan dari model jarum hipodermik (Ardianto, dkk, 2007). Selanjutnya dikatakan bahwa model Uses and Gratifications, meneliti asal mula kebutuhan manusia secara psikologis dan sosial, yang menimbulkan harapan harapan tertentu dari media massa atau sumber-sumber lain (keterlibatan pada kegiatan lain) dan menimbulkan pemenuhan kebutuhan. McQuail dalam Ardianto, dkk (2007) mengatakan, ada dua hal utama yang mendorong munculnya pendekatan penggunaan media ini. Pertama, ada opisisi terhadap pandangan deterministis tentang efek media. Sikap ini merupakan bagian dari penemuan kembali manusia, yang terutama terjadi pada sosiolog di Amerika. Kedua, adanya keinginan untuk lepas dari debat yang berkepanjangan tentang selera media massa.

Model Uses and Gratifications meliputi pemikiran yang berkaitan dengan anteseden yang terdiri dari variabel individual dan variabel lingkungan. Motif terdiri dari personal, diversi, dan personal identity. Penggunaan media terdiri dari hubungan, macam isi, dan hubungan dengan isi. Efek terdiri dari kepuasan dan pengetahuan (Rakhmat, 2007).

Asumsi dasar dari teori Uses and Gratifications, adalah: 1) Khalayak dianggap aktif, artinya khalayak sebagai bagian penting dari penggunaan media massa diasumsikan memunyai tujuan; 2) Dalam proses komunikasi massa, inisiatif untuk mengaitkan pemuasan kebutuhan dengan pemilihan media terletak pada khalayak; 3) Media massa harus bersaing dengan sumber-sumber lain untuk memuaskan kebutuhannya. Kebutuhan yang dipenuhi media lebih luas. Bagaimana kebutuhan ini terpenuhi melalui konsumsi media amat bergantung pada perilaku khalayak yang bersangkutan; 4) Tujuan pemilih media massa disimpulkan dari data yang diberikan anggota khalayak, artinya orang dianggap cukup mengerti untuk melaporkan kepentingan dan motif pada siatuasi-situasi tertentu; 5) Penilaian tentang arti kultural dari media massa harus ditangguhkan sebelum diteliti lebih dahulu 
orientasi khalayak (Ardianto, dkk, 2007).

Pandangan berikutnya melihat bahwa masyarakat bukanlah kelompok yang pasif dalam posisi sebagai penerima informasi yang ditandai oleh kebutuhan mereka untuk mendapatkan kepuasan dari media massa yang dirujuk. Putusan perkembangan selanjutnya mengarah kembali kepada pandangan bahwa media massa dapat "berpengaruh penuh" (powerful effect), dengan suatu persyaratan tertentu, dalam melakukan tindak komunikasi terhadap khalayak (Rusadi, 1994).

Menurut Katz, Gurevitch, dan Hass, penggunaan media meliputi isi media, jenis media, terpaan media dan situasinya, misalnya di rumah atau di luar rumah, sendiri atau dengan orang lain. Penggunaan media juga dilandasi oleh kebutuhan perorangan yang dipengaruhi oleh lingkungan sosialnya berdasarkan persepsi selektif individu (Severin dan Tankard, 2005). Adapun kebutuhan perorangan meliputi kebutuhan kognitif, kebutuhan afektif, kebutuhan akan integrasi personal, integrasi sosial dan kebutuhan untuk menghindarkan diri. Lingkungan sosial yang dimaksud ialah ciriciri demografi yang dicerminkan dalam lingkungan desa dan kota, afiliasi, kelompok, dan ciri-ciri pribadi (Rusadi, 1994).

\section{Model Uses and Gratifications} membahas pula motif-motif dan alternatif fungsional untuk memenuhi kebutuhan. Contoh: pemikiran untuk yang memakai pendekatan penggunaan dan gratifikasi adalah: individu tertentu, seperti halnya sebagian besar manusia, memunyai kebutuhan dasar untuk mengadakan interaksi sosial. Dari pengalamannya, individu ini berharap bahwa konsumsi atau penggunaan media massa tertentu akan memenuhi sebagian kebutuhannya itu. Hal ini menuntunnya pada kegiatan menonton program televisi tertentu, membaca isi majalah tertentu, dan sebagainya (Ardianto, dkk, 2007).

Dalam suatu penelitian terhadap penggunaan televisi oleh anak-anak, Brown dalam Ardianto, dkk (2007) mempelihatkan pentingnya media itu dalam sifatnya yang multi fungsional dan kemampuannya memberikan kepuasan yang bervariasi kepada sebagian besar anak-anak, seperti memberi penjelasan tentang bagaimana orang hidup di dunia dan memberikan bahan diskusi di antara anak-anak tersebut.

Ada beberapa hal yang memengaruhi kebiasaan seseorang dalam mencari informasi, antara lain adanya intuisi kebutuhan (need of cognition) yaitu suatu kebutuhan yang dekat hubungannya dengan rasa ingin tahu. Intuisi kebutuhan akan muncul sebagai variabel yang mempengaruhi perhatian seseorang terhadap isi pesan komunikasi (Depari, 1982).

\section{METODE PENELITIAN}

Penelitian ini bersifat deskriptif (deskriptive studies) dengan pendekatan kuantitatif (Nazir, 2003). Maksud dari mertode ini adalah menuturkan, menganalisis, menafsirkan, serta menglasifikasikan realitas sosial tentang kepuasan baca masyarakat terhadap pers berbahasa Sunda.

Populasi dalam penelitian ini adalah masyarakat pembaca pers berbahasa Sunda yang tersebar di 2 (dua) kecamatan, yaitu Kecamatan Bogor Tengah dan Kecamatan Bogor Selatan Kota Bogor yang berjumlah 500 pembaca yang terdiri dari 270 pembaca di Kecamatan Bogor Tengah dan 230 pembaca di Kecamatan Bogor Selatan. Teknik pengambilan sampel dilakukan secara acak. Terpilih 50 orang sebagai responden (Bulaeng, 2004).

Operasional konsep dalam penelitian ini adalah sebagai berikut: kepuasan, diukur dari motif masyarakat membaca pers berbahasa Sunda, pengetahuan masyarakat tentang pers berbahasa Sunda, dan kepuasan masyarakat terhadap pers berbahasa Sunda.

Masyarakat pembaca dalam penelitian ini adalah pembaca pers berbahasa Sunda yang tersebar di 2 (dua) kecamatan, yaitu Kecamatan Bogor Tengah dan Kecamatan Bogor Selatan Kota Bogor.

Pers berbahasa Sunda adalah pers 
nasional atau pers daerah yang terbit di wilayah Provinsi Jawa Barat dengan bahasa yang dipergunakan adalah bahasa Sunda. Di antaranya adalah Surat Kabar Mingguan (SKM) Galura, Majalah Mingguan Mangle, SKM Giwangkara.

Teknik pengumpulan data dilakukan dengan menyebarkan daftar pertanyaan yang tertuang dalam kuesioner. Data sekunder diperoleh instansi pemerintah maupun swasta yang berhubungan dengan penelitian, serta informasi lain yang signifikan dari berbagai media seperti; media cetak, internet, dan media lainnya. Pengolahan data dilakukan dengan mengolah jawaban yang dimasukkan dalam tabel tunggal dan dari tabel tersebut dianalisis secara deskriptif.

\section{HASIL PENELITIAN DAN PEMBAHASAN}

\section{Hasil Penelitian}

Responden dalam penelitian ini berjumlah 50 orang, terdiri dari 35 responden laki-laki dan 15 responden wanita. Usia responden terdiri dari 25 orang berusia antara 41-50 tahun, 15 orang usia antara 31-40 tahun, 9 orang usia antara 51-60 tahun, dan satu responden yang berusia antara 60 tahun ke atas. Data tersebut menunjukkan bahwa masyarakat pembaca pers berbahasa Sunda rata-rata masih berusia muda. Kondisi ini menunjukkan bahwa pers berbahasa Sunda tidak hanya merupakan konsumsi para orang tua.

Sebagian besar responden berpendidikan SLTA yaitu 42 orang, 6 orang berpendidikan Sarjana, dan 2 orang berpendidikan Diploma/Sarjana Muda. Data ini menunjukkan bahwa tingkat pendidikan masyarakat pembaca pers berbahasa Sunda dinilai cukup mampu memberikan jawaban sesuai dengan tujuan penelitian ini. Masyarakat pembaca pers berbahasa Sunda sebagian besar bekerja sebagai pegawai negeri sipil (PNS), pegawai swasta, dan wiraswasta.

\section{Motif Masyarakat Membaca Pers Berbahasa Sunda}

Kepemilikan sarana komunikasi, masyarakat pembaca pers berbahasa Sunda menunjukkan sebanyak 48 responden $(42 \%)$ memiliki handphone, 37 responden memiliki fasilitas internet (31\%), dan 33 reponden memiliki telepon kabel (27\%), sebanyak 48 responden memiliki pesawat televisi (31\%), 35 responden memiliki fasilitas internet (26\%), 19 responden memiliki pesawat radio $(12 \%)$, dan 16 responden berlangganan majalah (10\%).

Cara mendapatkan majalah berbahasa Sunda, sebanyak 42 responden berlangganan pers berbahasa Sunda (84\%), dan 8 responden membaca secara eceran (16\%). Sebanyak 20 responden membaca pers berbahasa Sunda antara 2-3 tahun (40\%), 12 responden membaca antara 1-2 tahun (24\%), 4 responden membaca antara $7-12$ bulan (8\%), 4 orang responden membaca antara 3-4 tahun $(8 \%)$, dan 2 responden membaca pers berbahasa Sunda antara 3-4 tahun (8\%). Sebanyak 3 responden membaca antara 5 tahun ke atas $(6 \%)$ dan 2 responden telah membaca pers berbahasa Sunda antara 4-5 tahun $(4 \%)$.

Sumber informasi terntang pers berbahasa Sunda sebagian besar diperoleh dari media yang bersangkutan yaitu sebanyak 27 responden (54\%). Sebanyak 17 responden mendapat informasi dari lingkungan kerja (34\%), dan sebanyak 6 responden memeroleh informasi dari pembaca sebelumnya (12\%).

Jenis pers berbahasa Sunda yang dimiliki, sebanyak 42 responden memiliki tabloid Galura (77\%), dan 12 responden memiliki majalah Mangle (23\%).

Sebanyak 44 responden (88\%) membaca pers berbahasa Sunda karena alasan bahasanya, dan 6 responden (12\%) karena isi pers berbahasa Sunda tidak terdapat pada media nasional.

Waktu membaca pers berbahasa Sunda, 23 responden $(35 \%)$ membaca pada siang hari, 20 responden $(31 \%)$ membaca pada malam hari, 8 responden (12\%) membaca pada pagi hari, 4 responden $(6 \%)$ pada saat sempatnya, dan 1 responden (1\%) membaca 
pada sore hari.

Sebanyak 26 responden (52\%) membaca di rumah dan 24 responden (48\%) membaca pers berbahasa Sunda di tempat kerja.

Adapun rubrik yang dibaca oleh responden, 41 responden (23\%) membaca hiburan, 33 responden (19\%) membaca berita, 27 responden $(15 \%)$ membaca rubrik agama, 27 responden (15\%) membaca seni dan budaya lokal, 15 responden $(8 \%)$ membaca seni budaya asing, dan 13 responden (7\%) membaca rubrik teknologi.

Sebanyak 40 responden (41\%) menyukai rubrik hiburan, 28 responden (29\%) rubrik seni budaya lokal, 18 responden $(18 \%)$ rubrik agama, 8 responden $(8 \%)$ rubrik pendidikan, 2 responden (2\%) menyukai berita, 1 responden (1\%) menyukai seni budaya asing, dan 1 responden (1\%) menyukai rubrik teknologi.

Tentang alasan menyukai rubrik dimaksud, 42 responden (84\%) menyatakan karena rubriknya dan 8 responden (16\%) karena bahasanya.

Tentang pemanfaatan pers berbahasa Sunda oleh keluarga, sebanyak 44 responden $(88 \%)$ menjawab ya dan 6 responden $(12 \%)$ tidak memanfaatkan pers berbahasa Sunda oleh keluarga.

Sebanyak 42 responden (84\%) menyatakan bahwa kendala yang dihadapi adalah kemampuan berbahasa Sunda dan 8 responden $(16 \%)$ memunyai kendala karena bahasa Sunda yang dipergunakan dalam pers berbahasa Sunda.

\section{Pengetahuan Masyarakat terhadap Pers Berbahasa Sunda}

Tentang pers berbahasa Sunda telah menjalankan fungsi sebagai media informasi, 44 responden (88\%) menjawab ya, dan 6 responden (12\%) menyatakan tidak. Sebanyak 50 responden (100\%) menyatakan pers berbahasa Sunda telah menjalankan fungsinya sebagai media hiburan.

Sebanyak 50 responden (100\%) menyatakan bahwa pers berbahasa Sunda telah menjalankan fungsinya sebagai media pendidikan. Tentang fungsi sosial, sebanyak
31 responden $(62 \%)$ menyatakan perbahasa Sunda telah menjalankan fungsi media sosial, dan sebanyak 19 responden (38\%) menjawab tidak.

$\begin{array}{lrrr}\begin{array}{c}\text { Sebanyak } \\ \text { menyatakan }\end{array} \text { pers } & \begin{array}{r}\text { responden } \\ \text { berbahasa }\end{array} & (100 \%) \\ \text { Sunda }\end{array}$
mengangkat budaya lokal. 44 responden (88\%) menyatakan bahwa pers berbahasa Sunda memenuhi kebutuhan informasi yang diperlukan, dan 6 responden $(12 \%)$ menyatakan tidak memenuhi.

\section{Kepuasan Masyarakat terhadap Pers Berbahasa Sunda}

Tentang pers berbahasa Sunda sesuai harapan, sebanyak 26 responden (52\%) menyatakan tidak memenuhi harapan, dan 24 responden (48\%) menyatakan memenuhi harapan. Tentang estetika, jumlah jawaban antara memenuhi dan tidak memenuhi harapan adalah sama, sebanyak 25 responden $(50 \%)$ menyatakan memenuhi dan 25 responden $(50 \%)$ menyatakan tidak memenuhi harapan. Tentang kepuasan terhadap pers berbahasa Sunda, 50 responden $(100 \%)$ menyatakan puas terhadap pers berbahasa Sunda yang dibacanya.

\section{Pembahasan}

Kepemilikan sarana komunikasi menunjukkan bahwa masyarakat pembaca pers berbahasa Sunda dalam penelitian ini telah memunyai dan menggunakan sarana komunikasi seperti handphone, fasilitas internet, telepon kabel, pesawat televisi, pesawat radio, dan berlangganan majalah.

Responden mendapatkan dan memiliki pers berbahasa Sunda dengan cara berlangganan dan membeli secara eceran. Data ini menunjukkan bahwa pers berbahasa Sunda menjadi pilihan untuk menjadi pelanggan tetap pada setiap edisi terbit.

Data sumber informasi tentang keberadaan pers berbahasa Sunda diperoleh dari perusahaan media yang bersangkutan, selanjutnya responden memeroleh informasi dari lingkungan kerja, dan memeroleh informasi dari pembaca sebelumnya. Data di atas menunjukkan bahwa masyarakat 
pembaca memeroleh informasi tentang keberadaan pers berbahasa Sunda dari lingkungan tempat bekerja. Jawaban ini sesuai dengan status pekerjaan responden yang sebagian besar adalah PNS. Hasil penelitian ini menunjukkan bahwa pola pemasaran antara perusahaan pers berbahasa Sunda dengan pelanggannya bersifat dua arah dan sedikit menggunakan media promosi dengan menggunakan media lain seperti iklan.

Pers berbahasa Sunda yang dimiliki oleh responden terdiri dari dua pers berbahasa Sunda, yaitu tabloid mingguan Galura dan majalah Mangle. Selanjutnya juga diperoleh data hanya dua jenis pers berbahasa Sunda yang beredar atau diminati oleh pembaca yang ada di wilayah penelitian ini.

Alasan responden membaca pers berbahasa Sunda sebagian besar menyatakan karena alasan bahasanya dan karena isi pers berbahasa Sunda tidak terdapat pada media nasional. Jawaban responden ini menunjukkan bahwa masyarakat membaca pers berbahasa Sunda karena motif bahasa yang digunakan.

Masyarakat pembaca pers berbahasa Sunda menggunakan waktunya untuk membaca di tempat kerja dan di rumah. Membaca pers berbahasa Sunda telah menjadi aktivitas rutin masyarakat di tempat kerja maupun di rumah.

Rubrik yang disukai responden dari pers berbahasa Sunda adalah rubrik hiburan, rubrik seni budaya lokal, rubrik agama, rubrik pendidikan, dan berita. Walaupun dalam persentase yang kecil ada responden yang menyatakan menyukai rubrik seni budaya asing, dan rubrik teknologi. Alasan menyukai rubrik tersebut karena bahasanya. Jawaban responden di atas menunjukkan bahwa sesuai dengan karakteristiknya, masyarakat pembaca memunyai motif untuk memeroleh hiburan dalam membaca pers berbahasa Sunda.

Tentang pemanfaatan pers berbahasa Sunda oleh keluarga, sebagian responden menyatakan bahwa keluarga reponden memanfaatkan/membaca pers berbahasa Sunda dan terdapat jawaban dalam persentase yang kecil bahwa keluarga responden tidak memanfaatkan pers berbahasa Sunda oleh keluarga. Jawaban di atas menunjukkan bahwa pers berbahasa Sunda yang dimiliki juga menjadi bahan bacaan bagi anggota keluarga responden.

Kendala yang dihadapi responden dalam menggunakan pers berbahasa Sunda adalah kemampuan berbahasa Sunda karena bahasa Sunda yang digunakan dalam pers berbahasa Sunda adalah bahasa Sunda. Kendala secara spesifik di antaranya karena terdapat pemakaian bahasa Sunda halus dan istilah kata Sunda yang jarang digunakan dalam bahasa pergaulan sehari-hari.

Pers berbahasa Sunda telah menjalankan fungsi media informasi dan telah menjalankan fungsinya sebagai media hiburan. Hal ini menunjukkan masyarakat mengetahui bahwa pers berbahasa Sunda memunyai fungsi sebagai media informasi dan media hiburan.

Selain telah menjalankan fungsinya sebagai media informasi dan media hiburan, responden mengetahui bahwa pers berbahasa Sunda telah menjalankan fungsinya sebagai media pendidikan. Data ini menunjukkan bahwa seluruh masyarakat pembaca dalam penelitian ini mengetahui bahwa pers berbahasa Sunda sebagai media pendidikan dan berfungsi sebagai media sosial.

Berkaitan dengan budaya lokal, seluruh responden menyatakan pers berbahasa Sunda telah mengangkat budaya lokal. Pers berbahasa Sunda telah memenuhi kebutuhan informasi yang diperlukan. Sesuai dengan pengetahuan masyarakat tentang fungsi hiburan dan fungsi sosial, seluruh masyarakat pembaca mengetahui bahwa pers berbahasa Sunda mengangkat budaya lokal dan memenuhi kebutuhan informasi pembacanya.

Dalam hal kepuasan terhadap pers berbahasa Sunda, sebagian besar responden menyatakan bahwa pers berbahasa Sunda tidak memenuhi harapan, lebih rendah persentasenya yang menyatakan bahwa pers berbahasa Sunda telah memenuhi memenuhi harapan. Tentang estetika, terdapat jawaban yang sama yaitu pers berbahasa Sunda telah memenuhi dan tidak memenuhi harapan dalam hal estetika/perwajahan dalam tampilannya. Namun demikian seluruh responden menyatakan puas dengan kondisi 
pers berbahasa Sunda yang dimilikinya.

\section{PENUTUP}

\section{Simpulan}

Motif masyarakat membaca pers berbahasa Sunda karena alasan bahasa yang digunakan yaitu bahasa Sunda. Motif lainnya karena isi yang ada dalam pers berbahasa Sunda tidak ditemui dalam pers berbahasa nasional/pers nasional. Selain itu juga pers berbahasa Sunda menyajikan budaya lokal, dalam dalam hal ini budaya lokal Sunda.

Pengetahuan tentang fungsi pers berbahasa Sunda cukup memadai. Masyarakat pembaca menilai bahwa pers berbahasa Sunda telah menjalankan fungsinya sebagai media informasi. Masyarakat pembaca menilai bahwa pers berbahasa Sunda telah menjalankan fungsinya sebagai media hiburan.

Pers berbahasa Sunda tidak memenuhi harapan pembaca, namun demikian, masyarakat pembaca menyatakan puas terhadadap keberadaan pers berbahasa Sunda.

\section{Saran}

Kepada pengelola pers berbahasa Sunda untuk meningkatkan kualitas substansi tulisan yang berhubungan dengan segala aspek tentang Sunda. Perlu dibedakan antara pers Sunda dengan pers berbahasa Sunda. Pers berbahasa Sunda tidak hanya menyajikan informasi hanya dengan mempergunakan bahasa Sunda, tetapi harus berisi dan memunyai makna kesundaan.

Pers berbahasa Sunda hendaknya mengedepankan pendekatan emosional dengan pembacanya. Di antaranya, mengeksplorasi materi tulisan yang menyentuh langsung sisi kehidupan pembacanya seperti masalah budaya, sosial, dan lingkungan.

\section{DAFTAR PUSTAKA}

\section{Buku:}

Ardianto, Elvinaro, dkk. (2007). Komunikasi Massa, Suatu Pengantar. Bandung: Simbiosa Rekatama Media.

Bulaeng, Andi. (2004). Metode Peneltian Komunikasi Kontemporer. Yogyakarta: Andi Ofset.

Dilla, Sumadi. (2007). Komunikasi Pembangunan, Pendekatan Terpadu. Bandung: Simbiosa Rekatama Media.

Depari, SR. (1982. Prospek Bisnis Informasi di Indonesia (ed. Sumarsono Suniardja). Yogyakarta: Pustaka Pelajar.

Mulyana, Deddy. (2004). Komunikasi Populer: Kajian Komunikasi dan Budaya Kontemporer. Jakarta: Pustaka Bani Quraisy.

Nazir, Moh. (2003). Metode Penelitian. Jakarta: Ghalia Indonesia.

Rakhmat, Jalaluddin. (1985). Psikologi Komunikasi. Bandung: Remaja Rosda Karya.

$$
\text { ..(2007). }
$$

Metode

Penelitian Komunikasi. Bandung: Remaja Rosdakarya.

Severin, Werner J dan James, W Tankard JR. (2005). Teori Komunikasi; Sejarah, Metode, dan Terpan di Dalam Media Massa. Jakarta: Pranada Media

\section{Jurnal:}

Rusadi, Udi. (1994). Penggunaan Media Massa. Jurnal Penelitian dan Komunikasi Pembangunan. Edisi Khusus No.1, hal. 22-31.

\section{Majalah:}

Anonim.(2006).Pers Berbahasa Sunda Masa Kini. Majalag Gatra. Hal. 29.

\section{Perundangan:}

Undang-Undang Nomor 40 Tahun 1999 tentang Pers. 